Article

\title{
(Self-)Reflecting on International Recruitment: Views on the Role of Recruiting Agencies in Bulgaria and Romania
}

\author{
Siyka Kovacheva ${ }^{1,2, *}$, Boris Popivanov ${ }^{2,3}$ and Marin Burcea ${ }^{4,5}$ \\ ${ }^{1}$ Department of Applied Sociology, Plovdiv University Paisii Hilendarski, 4000 Plovdiv, Bulgaria \\ 2 New Europe Centre for Regional Studies, 4002 Plovdiv, Bulgaria; E-Mail: skovacheva@neweurope-research.eu (S.K.) \\ 3 Department of Political Science, Sofia University St. Kliment Ohridski, 1504 Sofia, Bulgaria; \\ E-Mail: bpopivanov@phls.uni-sofia.bg \\ ${ }^{4}$ Centre for Urban and Regional Sociology, 011038 Bucharest, Romania \\ ${ }^{5}$ Department of Economic and Administrative Sciences, University of Bucharest, 030018 Bucharest, Romania; \\ E-Mail: marin.burcea@faa.unibuc.ro \\ * Corresponding author
}

Submitted: 19 June 2019 | Accepted: 26 August 2019 | Published: 7 November 2019

\begin{abstract}
This article focuses on the recruiting practices of public and private agencies dealing with international labour mediation in Bulgaria and Romania. Based on interpretative analysis of 20 in-depth interviews with professionals working in migrant recruiting agencies in the two countries, we aim to understand their views on the advantages and disadvantages of their services in comparison with other mobility channels: such as informal networks, direct contacts with employers, or unofficial Internet sites. The article examines the ways in which international labour mediation practitioners construct their target group-migrants-in terms of motivation, human capital, and/or challenges of their adaptation to the new context. We then look at intermediaries' perceptions of employers' needs and expectations. We finish with uncovering recruiters' underlying assessment of the national and European mobility policies and the outcomes they see for individual migrants, employers and the countries of departure and destination.
\end{abstract}

\section{Keywords}

Bulgaria; European Union; labour market; labour mediation; migration; mobility; recruiting agencies; recruitment; Romania

\section{Issue}

This article is part of the issue "The Lived Experiences of Migration: Individual Strategies, Institutional Settings and Destination Effects in the European Mobility Process" edited by Neli Demireva (University of Essex, UK) and Fabio Quassoli (University of Milano-Bicocca, Italy).

(C) 2019 by the authors; licensee Cogitatio (Lisbon, Portugal). This article is licensed under a Creative Commons Attribution 4.0 International License (CC BY).

\section{Introduction}

Emigration has had a prominent presence in public debates in the two European Union (EU) member statesBulgaria and Romania-ever since 1989 when the two countries experienced a regime change from communism to multiparty democracies (Valsan, Druica, \& lanole, 2015). Both countries opened their state borders and introduced the right to free movement together with many other human rights that had been suppressed during the communist regime. Media discourses, however, do not welcome the expansion of mobility rights so much but rather focus on the negative consequences of emigration. The dominant construction in Bulgaria is that emigration is contributing to the depopulation of the country (Belcheva, 2011; Mintchev et al., 2012) while in Romania it is generally seen as destroying family relations when migrants leave their children and elderly parents behind 
(Tyldum, 2015). Among the economic costs, the most featured are labour shortages in certain sectors, such as healthcare (Druica \& lanole-Calin, in press), ageing of the workforce, and the 'brain drain' (Alexe et al., 2011; Beleva \& Dimitrov, 2016; Ionescu, 2015). From a political perspective, emigration is weighted to lean toward the negative side of the equation reducing the protest 'voice' inside the country (Krastev, 2014). Less attention is paid to research arguments for the positive effects, such as remittances sent home by migrants (Goschin, 2014; Open Society Institute [OSI], 2010) or the rise in skills (Kostadinova, 2007) and enriched identities (Zeleva \& Draganova, 2015).

In the public debate in the two countries, the organisations regulating migration flows remain invisible. Academic research commonly emphasises the role of informal channels for migration (Markova, 2006; OSI, 2010) showing that Bulgarian and Romanian diasporas' (family social capital) 'weak' ties act as recruiting channels trusted by prospective migrants. In this article we examine the role of public and private organisations specialising in international labour mediation. We draw upon qualitative interviews with experts and practitioners on different organizational levels inside such institutions which were explored as part of GEMM (Growth, Equal Opportunities, Migration \& Markets) project featured in this issue. Applying interpretative analysis, we look at how the professionals perceive the needs and expectations of prospective migrants and foreign employers, and how they construct the advantages of their own recruiting styles in trying to sell their services to both sides. Finally, we highlight the underlying assumptions about the implications of the EU free movement policies that the agency workers see for individual migrants and the countries of departure and acceptance.

\section{Legal and Institutional Context of Mobility in Bulgaria and Romania}

The process of migration is situated in a particular social time and place, rendering specific features to the migration flows. The level of the flow, the motivations and channels used by the migrants are grounded in both the sending and receiving context. In the 1990s, there was a high emigration flow from Bulgaria and Romania. It was linked to the economic difficulties in the first decade of transition from the centrally planned to a market economy characterised by privatization and closure of many state-owned enterprises and a steep rise of unemployment. While the former communist countries opened their state borders for those wishing to leave, in a shift from maximum control to a liberal emigration policy, the borders of the EU countries remained largely closed and the former's citizens needed visas even for short-term tourism. So, this first emigration wave used mostly informal channels of migration and illegal work was the main form of migrants' integration in the receiving labour market. The key sectors incorporating mi- grants were hospitality, cleaning, construction and trade (OSI, 2010). After 2000, with the improvement of the economic prospects, the emigration wave started to decline and migration became mostly temporary, in comparison with previous stages when many young people left for good (Atoyan et al., 2016; Stanchev, 2005). The composition of the flow diversified, increasing the shares of skilled migrants and middle-aged women. Students became a significant group among migrants, seeking undergraduate and post-graduate degrees in Western universities, and many stayed after graduation in more or less qualified jobs (Mintchev et al., 2012). The economic crisis of 2008 did not lead to the expected mass return of emigrants, but rather slowed down the emigration flows (Krasteva, 2014).

The present post-2014 stage started with another policy change when the last EU countries, including the UK, lifted the restrictions to the internal market for Bulgarians and Romanians. It was marked with a new increase in emigration. With the new refugee influx in Europe, many state institutions in Romania and Bulgaria focused on dealing with immigrants and the regulation of their entry, work and social integration, and paid less attention to outmigration, which was still much higher than the inflow of immigrants.

In the last period, unlike earlier ones, the state has become increasingly involved in labour mediation. As significant policy actors in the two countries are established, the public employment agencies which are members of the European Job Mobility Network (EURES) have specialised EURES advisors among their employees to provide services to job seekers and employers in the EU. There are also labour and social policy offices at some of the diplomatic missions in EU countries. Further, bilateral agreements foster mobility abroad-both within and beyond the EU. However, these practices are criticised for providing unequal opportunities through selective and hierarchical immigration policies (Blitz, 2014).

Since lifting barriers, private mediating agencies also became increasingly active in the field of recruitment of potential emigrants. They are obliged to register officially but some are not licensed and recruit people for low-qualified jobs and no decent working and living conditions. In this way, these 'migration industry' actors in Bulgaria and Romania reflect both processes of expansion of intermediaries in international labour migration (known in Europe and beyond) and deficiencies in control, equal treatment and respect for migrants' rights characteristic for their functioning (cf. van den Broek, Harvey, \& Groutsis, 2015). Many internet sites also offer work placements under the heading 'Directly from Employer' and recruit care workers. Ethnic businesses in the receiving country (jobs created by co-nationals for conationals) offer short-term opportunities but might act as a trap in the longer run as they reduce opportunities for growth and integration in the host society (Bloch \& McKay, 2015). Characteristically, despite the huge variety of opportunities for labour mobility, the intermediaries 
sector takes advantage mostly of the basic premise of free EU movement and rights to work in the EU member states. This is also the focus of our study.

\section{The Agency of Intermediaries as a Research Area}

This article builds upon a body of research that examines the role of recruiting agencies for matching the demand and supply of skills on a global scale (International Labour Organisation [ILO], 2013; Martin, 2005; Organisation for Economic Cooperation and Development [OECD], 2016). Fewer studies have concentrated on mobility mediation practices in the European labour market (Green, Atfield, Staniewicz, Baldauf, \& Adam, 2014; Rolfe \& HudsonSharp, 2016) where public and private agencies are expected to facilitate the allocation and utilisation of human resources in the European labour market and foster economic growth. A bulk of this research has been investigating agencies recruiting Eastern European migrants to the regional markets in the more developed Western economies which experience shortages of specific skills (Friberg \& Eldring, 2013; Jones, 2014). As a rule, most of the studied agencies are registered in the West and often act as employers themselves, offering flexible forms of employment to recent migrants from Eastern Europe. There is a scarcity of literature throwing light upon the practices of agencies registered and functioning in Bulgaria and Romania that send migrants to other EU countries. These agencies became more visible after 2007, the year of both countries' EU accession, in a (rather unfavourable) context: when the boom of Eastern European migrants had already started to decline (Jones, 2014), and the economic recession had begun to shrink the demand of foreign labour in the Western markets while Southern European countries (such as Italy, Spain and Greece) started sending migrants to the North. For some time, immigration restrictions for Bulgarians and Romanians were still in force in several EU countries (for e.g., in Germany and in the UK), and such controls officially regulated the number of incoming migrants and were also used to channel new migrants into unskilled and precarious employment (Anderson, 2010; Sporton, 2013).

Cross-border mobility involves high-transaction costs both for workers and employers, so recruiting agencies seek to gain profit by offering services and brokerage to both sides. With the increasing global flows, they became actors in a new area of commercial profit named 'migration industry' (Gammeltoft-Hansen \& Nyberg-Sørensen, 2013; Salt \& Stein, 1997) or 'migrant recruitment industry' (ILO, 2017). The industry is very diverse-from small firms and individual brokers to large multinational corporations. In fact, it is viewed by scholars as a complex ensemble of actors and actions in the field of international migration which should not be reduced to business and infrastructure, although both play a substantial role. Migration industries and labour markets are found to be mutually constitutive as the former develop together with the moves for migration management procedures within the latter (Cranston, Schapendonk, \& Spaan, 2018; Nyberg-Sørensen, 2012). In such a perspective, intermediaries do not just intermediate. Migration industries appear to produce a need for themselves in the migration processes through the knowledge they claim to possess. Labour market is not a given reality but rather actively produced arena in which intermediating actors execute transformative and not simply facilitating, structuring and controlling functions (Coe, Johns, \& Ward, 2010; Cranston, 2018).

Seeking profit is not valid for the public agencies, which, instead, serve policy objectives established by the EU. Yet, the efficiency of their work is measured by similar quantitative criteria as those of private brokers: the number of matches between workers with employers. While ILO Convention no. 97 (ILO, 1949) recommended the mobility over borders only with the help of no-fee charging public employment agencies, the later Convention no. 181 (ILO, 1997) endorsed the legitimacy of services offered by private, for-profit employment agencies. The European Commission has consistently seen both types of the recruitment services as means to remove barriers to the free movement of labour. Recruitment agencies have now become embedded as important actors in transnational labour mobility.

Migration brokers act in a triangular set of relationships, mediating between workers and employers on meeting their needs and aspirations. But this relationship is not symmetrical, as employers exert more power and control than the potential employees and recruiters (Sporton, 2013). The main asset of recruiting agencies is their knowledge of workers willing to migrate and contacts with employers looking for workers to fill the labour shortages (Martin, 2005). The agencies claim to possess knowledge on both sides-supply and demandbeing aware of the qualities of potential migrants and the structure of the labour market. They compete for clients in order to generate profits and seek to develop growth strategies (Grey, 2002). Their success depends on the speed with which they can provide suitable workers to the employers' demands. Yet, there is a high level of uncertainty in the process, so trustworthiness and good reputation are very important for the intermediaries (Friberg \& Eldring, 2013). Current research extends to the issue of reputation of migratory destinations and the increasing role of intermediaries in shaping it (Harvey, Groutsis, \& van den Broek, 2018) but rarely treats the reputation of the mobility framework in general, particularly of the EU.

The act of matching demand and supply is not neutral (Jones, 2014). The biggest advantage of migrants from less developed economies is that they are employees who are unlikely to complain about working conditions (Burawoy, 1976). At the same time, it should be noted that perceptions about needed workers are socially constructed and may vary. In previous research, it is extensively demonstrated that intermediaries are actively in- 
volved in the process, apart from employers. Recruiters provide categorisation of the desirability of some forms of migration, thus influencing the labour market structure in the destination country, and engage in calculations about which migrants fit into existing national cultures, thus discriminating on ethnic basis (Kofman, 2008). Images of the 'ideal worker' and the 'good migrant' emerge through the work of recruiters whose motivation, after all, is to supply a desirable product. In this way, intermediaries produce embodied imaginaries of international migration by applying social and cultural and not just economic decisions of recruitment. Bodily appearance, self-discipline, realistic expectations are regularly included. Sex, age, nationality do matter, despite legal provisions. The 'ideal worker' corresponds to elusive requirements of employers, therefore it is accomplished only in the imaginary where the agency of recruiting agents is vital (Findlay, McCollum, Shubin, Apsite, \& Krisjane, 2013; Shubin, Findlay, \& McCollum, 2014). Academic debate in these directions has been increasingly occupied with cases of Central and Eastern migrants, and against this background, the scarcity of research on Bulgarian and Romanian examples becomes even more striking.

\section{Data and Methods}

This article contributes to the debate on recruiting agencies by examining the practices of those situated in the specific context of Bulgaria and Romania after the dropping of formal restrictions to the free movement of their nationals in Europe. In addition, our research adds to the debate the views and self-reflection of the recruiters themselves, highlighting the agency of the practitioners working in the agencies. We look into the ways they explain their actions and approaches and the meanings they attribute to them.

The analysis here draws upon qualitative interviews with experts from recruiting agencies conducted in Bulgaria and Romania during the period from November 2016 to April 2017 as part of the GEMM project. The research combined quantitative and qualitative methods to study the barriers to European mobility, the factors for the successful incorporation of migrants in the receiving societies and how the multi-dimensional process of migration can be managed to increase the potential for EU competitiveness and growth. One of the project strands focused on the 'lived' experiences of mobility, captured by in-depth interviews with different groups involved in the process: 'prospective' migrants (people who plan to move for work to a foreign country in less than a year); 'actual' migrants (who have lived for at least two years in a foreign country); and 'experts' from recruiting agencies (professionals in public and private agencies dealing with international labour mediation).

The project explored the latter group in Italy, Spain, Romania and Bulgaria, and each national team conducted about ten interviews with representatives of mediation services. Here we focus on the two Eastern European countries, which represent a rather similar context of 'migrant sending' countries, while the flow from the two Southern European ones has higher specificity to be dealt with in one article. The common situation with the sector of migrant recruiting agencies in both countries, the similar political and economic framework, and the common methodology of the study allowed us to present the findings in Bulgaria and Romania together.

We aimed to include equal numbers of representatives of private and public agencies and to achieve maximum diversity beyond this indicator (see Table 1). While public employment services and their EURES advisors were easily identifiable, the private companies were more difficult to find. They were selected from the official lists of registered organisations in both countries, but some did no longer exist or no longer dealt with international labour mediation. The private agencies that took part in our study were much smaller than the network of the regional and local employment agencies and reported having one to three employees. Most were independent agencies, while a few were members of ADECCO (one of the world largest human resourcesproviding company) or of (bigger and older) Polish private recruiting agencies. Most of them recruited workers for both high- and low-skilled sectors of the economy and in a wide range of countries, with those in Romania having a broader transnational span.

The interviewees (one from each organisation) were employees on different levels of the organisational hierarchy: half of them were managers and one was the owner of a private agency. The professionals working in the public agencies agreed to be interviewed after being assured of the anonymity of their responses. Those working in the private companies, in addition to anonymity, insisted that no financial details would be discussed. In some cases, two and more meetings were necessary to establish trust with the interviewees (managers and employees) before getting final permission for the interview. During the fieldwork, we managed to establish contacts with key experts who knew how their companies started and changed in the course of development. All had post-

Table 1. Selection of recruiting agencies in the GEMM study.

\begin{tabular}{|c|c|c|c|c|c|c|c|c|c|}
\hline & \multicolumn{2}{|c|}{ Type of agency } & \multicolumn{3}{|c|}{ Sector } & \multicolumn{4}{|c|}{ Destination countries } \\
\hline & Private & Public & Any & High-skilled & Low-skilled & United Kingdom & Germany & EU & Any \\
\hline Bulgaria & 6 & 4 & 6 & 1 & 3 & 1 & 2 & 4 & 3 \\
\hline Romania & 5 & 5 & 5 & 3 & 2 & 1 & 0 & 1 & 8 \\
\hline
\end{tabular}


secondary education with a third holding MA degrees. Most were women in mid- to late-career stages. Many of the interviewees had spent some time in a foreign country, had created links with employers there, and had some knowledge of the local labour market and business culture.

We adopted a qualitative approach in constructing the interview guide and stimulated the interviewees to tell their stories of what it was like to work in such organisations before covering the more specific topics about the policies and practices of cross-border mediation in the EU. The fieldwork started after receiving ethical approval from academic bodies in the two countries and interviewees were informed in detail about the aims and methods of the study. All interviews, lasting between 45 minutes to two hours, were audio recorded with the consent of the respondents and then fully transcribed with some details removed in respect of the anonymity of the participants and their organisations. Two researchers coded each of the narratives respecting the original language of the interviewees, making reference to the questions but also allowing room for specific terms and associations in the discourse of the interviewee and then derived emerging categories by identifying common themes and explanations (Glaser \& Strauss, 1967). We do not claim representativeness of our findings for the recruiting sector as a whole but tried to cover a wide range of recruiters' views and perspectives and developed understandings through accessing the meanings the interviewed migration intermediaries assigned to them.

\section{Self-Positioning and Target-Group Construction}

Since state and private migrant recruiting agencies act as mediators between foreign employers and local workers-candidates for jobs abroad-it is interesting to see how they assess their own role and construct their target groups. In this section we explore the perceptions of the labour mediators of themselves, the 'ideal applicant' and the 'ideal employer.'

Our study showed that in the triangular relationship the mediators considered that the applicants were the more problematic target group. Many of the interviewed professionals declared that they received more demands for employees coming from foreign employers than they could provide candidates for. This asymmetry did not make visible the privileged position of the employers who set up the number of openings and provided the fixed requirements for the qualities of the applicants. In the discourse of the experts from the public employment agencies-most of them heads of departments for international cooperation and EURES advisors-the role of the mediators was neutral, a mere 'connecting demand and supply.' In addition, they spoke about policy restrictions and the right of each EU member state to individually decide whether, how many, and what kind of labour immigrants it could accept. The figure of the employer re- mained in the backstage. In contrast, the managers of the private employment agencies stated they worked upon request by employers and were fully aware of the fact that their profit was coming from the fees which employers paid for each suitable applicant.

In the views of the recruiters from both types of agencies, the main difficulty in filling the vacancies was the 'language barrier.' Many depicted potential migrants as having high occupational skills but lacking knowledge of the local language. According to them, employers' requirements for the fluency of the candidates had increased significantly in the past ten years. Previously, many employers allowed exceptions, but the requirements in this regard had now increased. The interviewees also presented the candidates as not concerned and often negligent about this requirement. A low-level employee of a public recruiting agency in Romania, a man in his forties, explained: "Many people think that without the language they can go and work. And they do, but problems arise from lack of communication between the worker and the employer. So, this is, in my view, the main obstacle to labour mobility." Some recruiters considered that for low-skilled workers in agriculture language knowledge was not essential because the employer usually provided a supervisor or manager who knew Bulgarian or Romanian and helped in the communication. However, for highly-skilled jobs in health care, finance, and IT, good knowledge was seen as a must.

In the views of the recruiters, job seekers paid even less attention to the challenges of working and living in a 'foreign culture,' even though the need to adapt to a foreign cultural milieu was another serious obstacle to labour mobility. As a high-level expert from a public agency in Bulgaria, a middle-aged woman, summarised it: "The failure to accept cultural differences between the countries...also creates conflicts and collisions....The clash of cultures actually leads to the employee's frustration. This is also one aspect that many people do not think about or underestimate." Very often this was portrayed as a contrast between the 'coldness' of the Western culture and the 'warmness' of 'our people.' The coldness was explained with 'the profit logic' in the country of arrival which was 'very quickly' accepted by Bulgarian and Romanian emigrants once in the new place. A young woman, EURES advisor from Bulgaria, stated:

We are used to helping and relying on each other here, while there everything is paid for. No one will come to pick you up, even from the airport, if you do not pay them. Here you can just show up at your friend's door and you will be invited to the table and given dinner, you'll talk and drink. You cannot see such a thing in the UK.

Among the negative images that often the recruiters conveyed about the applicants were their 'greediness': Many mediators constructed the motivation of migrants to go abroad as purely 'money'; applicants were looking only 
for the higher pay, did not want to spend time for training or learning the language. As an owner of a private agency in Bulgaria put it: "They never ask: 'Will I do the job, will I cope?' No, they only ask: 'What will I get, what is free?" Such 'greediness' was reported to lead some to engage in dishonest practices. A woman-manager in a private company in Romania pointed at attempts to unfair competition between women she recruited to work in nursing homes in the UK: Since their pay depended on the number of working hours, some of them took up to 80-90 hours a week, and disliked newcomers 'for fear not to have those extra hours reduced.'

These negative imaginaries were used to present the hard work that cross-border mediation entailed. The interviewees also offered descriptions of the ideal migrant' who was industrious, hardworking and determined to succeed. Some recruiters voiced the opinion that the success of those who had gone abroad to work was linked to their agency and hard work. A high-level expert from a public agency in Romania defined more clearly 'the personal qualities desired' of the applicants:

The successful emigrant is one who responds adequately to the situation, to the place. He searches for the opportunities in a particular situation...is not inclined to complain, not looking only at the negatives. These are just people who use the opportunities they currently have and wish to have, and are tolerant to others.

A EURES counsellor in Bulgaria, recently graduated from an MA course in Sofia, insisted that personal intelligence was a major factor for success. According to her, the migrants who managed to adapt successfully in the foreign country were intelligent people who had high professional and language skills and who "take into account the cultural differences, and, even when they cannot fit easily into the foreign cultural environment, they accept it, do not reject it, or do not complain about it." Such a fragmented view of the applicants largely corresponds to widespread discourses of the 'good worker' amid the recruitment practices in other Central and Eastern European countries. Research on Latvian migrants in the UK, for instance (Findlay et al., 2013; Shubin et al., 2014), finds similar representations of ability to work strenuously, to behave well, to accept the rules, and to adapt to the environment. Unlike Latvian cases, however, Bulgarian and Romanian recruiters do not mention bodily appearance as a crucial element of migrant success: The labour mediators in our study devoted less attention to the image of the employers in their interviews.

All interviewees claimed to work only with 'honest employers' who would not deceive migrants unlike the situation with informal recruiters. The experts and practitioners in both public and private agencies accepted that the motivation for employers was to find cheaper labour for their business but considered this motif fully legitimate. In their narratives they often spoke about the 'rights' of the employers to insist upon this or on the quality of the candidates, and did not question their requirements. Besides being honest, the 'ideal' employer, according to some of the practitioners in the private agencies, was the one who cared for the living conditions of the migrants and provided decent housing. A female recruiter from Romania stated that such a practice would attract more applicants and would act as an incentive for them to stay longer. A high-level manager from the public employment agency in Bulgaria added to the image of the 'good' employer a concern for the language training of the newcomers. According to him, foreign employers should invest more money into language courses if they wished to have more choice of skilled labour migrants. Under the rules of a 'migration industry,' it was perhaps natural to find intermediaries keen on providing the service rather than questioning the client preferences.

\section{Recruitment Practices}

Recruiters' perceptions of the target groups impacted their practices of cross-border labour mediation. The interviewed agency experts readily listed some similar procedures: information campaigns, consultations, selection of potential candidates, help for the preparation of documents and information about the country in which candidates wish to work, organising interviews between employers and job seekers, or doing the interviews themselves. Yet, there were some distinctive features that differentiated the activities of the two types of labour mediators.

The practitioners from public agencies received information about job vacancies mostly through the network of EURES advisers in the EU. They had a lot of printed advertising materials and used the well-developed national EURES sites in the two countries which made job openings visible to all interested candidates who could apply in their local employment office. They expected greater agency on the part of the job seekers, while the recruiters' role was more instrumental.

The official discourse in the public agencies was dominated by 'professionalism.' The interviewees explained in length that they offered sound advice by well-trained professionals and relied on the wide professional network of EURES offices in other European countries and a wider pool of vacancies: "We have EURES advisors, EURES assistants, psychologists, lawyers....We provide real professional help before people leave.....And then, if anything goes wrong, we can always get in contact with the EURES office in the other country."

The EURES advisors perceived their activities as completed after the contract between the employer and the candidate was signed, while subsequent stages in the migration process-such as adaptation and integration in the country of arrival-were not seen as their responsibility and were expected from employer's own discretion.

In contrast, maintaining relations with foreign employers were much more important for the private agen- 
cies and the mediators invested a lot in this activity, often working with only one employer or one economic sector. Thus, one agency was dealing with IT specialists only, another agency offered jobs in health care and another one in manufacturing. Few had their own websites and more often posted adverts on different job search sites. In addition, the private recruiters were more actively involved in searching for suitable candidates: instead of waiting for the applicants to contact them personally, they phoned potentially interested people. One female manager defined such personal activities of the mediators as 'network marketing': "We have neither a flyer, nor a website. We generally rely on the so-called network marketing-from person to person. Someone has gone abroad, is happy, he says this to 10 people, they start looking for us." This kind of semi-formal practice made the private mediators very flexible and allowed them to bypass some legal regulations which would otherwise limit their activities; for example, applying selection criteria that would be declared discriminatory if published. In the words of another mediator from Bulgaria:

Every employer has their own criterion. Some look for students, for example, for the summer only, for June-July-August. Other employers want people for longer-they, for example, want people who are not students and choose non-students. Some employers only want women. Others want only men. Others want people to come in couples. Every employer has different criteria that, in general, as a supervisor, I should meet, without officially declaring them.

The private agencies also invested more efforts in creating and maintaining profiles of the job seekers than the state experts, most of whom considered that this was the responsibility of the potential emigrants themselves. The recruiters had to provide the required number of candidates as fast as they could and, in the words of the interviewed owner of one agency, they often had to bring many more people to the interview than the required number. The manager of a public agency in Bulgaria admitted that the private agencies did a more rigorous selection than the public employment offices. For sure, private agencies were interested in sending more people to work and made more efforts to meet the demands of the employers, but they also recognised that they should not compromise on the selection of candidates because it would then create problems in their relationship with the employer. Moreover, growing negative prejudices against Eastern Europeans made recruiters stress the 'personal qualities' of applicants, such as being tolerant toward others and not inclined to instigate conflicts. One interviewee explained:

For example, there are-although we can never be sure-people who come here, and everything seemed fine, I found the skills appropriate.....But going there and starting drinking alcohol in the evenings and then fights with knives even....I have judged, it may be very subjective, but if there is such a threat, I tell them the job is not suitable and send them away dissatisfied, but that's part of the work that I have to do.

The services of the private agencies, unlike the public ones, did not end with the signing of contracts but continued in the subsequent stages of migration. The recruiters often arranged transport, accommodation, and sometimes help with administrative procedures in the country of arrival. They kept contact with their clients after migration and received feedback on a more regular basis. All EURES counsellors admitted that they did not usually get feedback except in cases when a problem had arisen. In contrast, the private mediators claimed to keep regular contacts and boasted about the souvenirs they received from satisfied clients.

The leitmotif in the interviews of private recruiters was the 'personal engagement,' both with employers' demands and with the job seekers' applications. A private agency employee claimed that the people in the state employment agency were 'very passive' and worked only for salaries, while she was personally engaged and interested in what she did:

We have a direct relationship with the particular employer and the particular worker. We have had many candidates who have gone to work in Europe through the Labour Offices, where the selection is very general. There is no individuality, no individual approach to each candidate, like a conveyor belt. People are not given detailed explanations about the conditions there for pay, for accommodation, for food. And they go abroad with quite different expectations and then come back dissatisfied.

Personal commitment to migrants, as advocated by private recruiters, can be compared to practices of corporate expatriate management across the world (Cranston, 2018). Corporate mobility is found to be exercised with the view of not only the technical (managing different steps of migration) but also the empathetic knowledge of recruiters. The latter denotes personal acquaintance with the conditions in the destination country, the ability to 'feel what it is like,' the upgrade of know-how with experience in order to thwart possible failure of the migratory move. Lacking the enormous capacities of multinational corporations, Bulgarian and Romanian private intermediaries tried to advertise themselves with a similar added value to the recruitment process. Many of the private recruiters pointed at the psychological labour they did in overcoming job seekers' hesitation and fears and reassuring them to deal with the unknown. A female manager from Bulgaria, who registered her own agency after a failed attempt at emigrating personally, offered the following explanation: 
A trip abroad-especially if the person has never been outside the country-is associated with a lot of stress, a lot of strain, a lot of nerves, and therefore, how to say, there is a lot of uncertainty, ignorance. And if the person does not know the language of the country, for example, then it is really scary. Accordingly, we are not only giving information and advising them about the work, etc., we are kind of helping them psychologically, too.

This reliance on personal emotional help contrasts with the discourse of the public mediators who stressed the existence of professional support in their organisations, provided to their clients, by trained psychologists.

\section{Perceptions of EU Mobility Policies}

The interpretative analysis of the narratives of the interviewees allowed us to highlight the underlying understandings by migration intermediaries of the mobility policy in the EU. When asked directly about their stance on the the current EU policy framework, all practitioners viewed its goals and effects positively. Those working in public agencies more often defined the free movement as a fundamental freedom of EU citizenship following the official policy discourse. All mediators cited the higher income that a foreign employment entailed as beneficial. The manager of one private agency insisted that this was a mutually useful exchange: cheap labour for employers abroad and saved money for emigrants upon return. Then he added some subtler effects:

Let me summarise: I think it's good and useful for everybody to at least try out what it is like working abroad-even for a shorter period of time-because they can learn a lot about it...in the sense that work abroad is based on completely different principles, and, as I said, the pay is better, in multiples. Everyone can try it. Most people are affected positively and come back with a good impression.

Rarely did the experts speak about the contribution of mobility within the EU to the economic growth in the EU as a whole. Some of them stated that their services contributed to the European integration but saw the effect again in individual terms-enriching experiences from living in another country, which made people more tolerant and open minded.

After initially declaring their positive attitude, several of the experts (both from public and private agencies in the two countries) expressed their scepticism and pointed at the negative effects of mobility. In their view, these were linked first to the labour shortages in the countries of departure, particularly in sectors such as health care. Some also added the losses of not using the skills and knowledge of emigrants that affect society as a whole, although none specifically used the term 'brain drain.' Others spoke about the negative consequences on migrant families caused by the separation of family members. As one mediator from Romania explained:

Social relations suffer, children suffer....Generations of children who grow up only with grandparents because parents are abroad-and I am speaking about massive numbers....This, then, has a negative impact on their relationships, in general, with people and also on their health-emotionally and psychologically....So, the effect is very large, very deep and very unpleasant.

Given that many mediators expressed concerns that their home countries were deprived of labour and skilled workers it was understandable that both private and public agency experts found it difficult to suggest any policy recommendations for better managing the European mobility. One EURES counsellor considered that their services needed an 'improved feedback,' without being able to identify a means to achieve it. Another public agency expert spoke about the need to employ more people as administrative staff working on European mobility and 'increase their potential' through more training. A manager from the employment agency in Bulgaria considered that the state should improve the conditions in the country, so that people stay there. She went even further, proposing that the Bulgarian state should discourage people from leaving the country while encouraging others to come and settle down in the country. This should be limited to people with ethnic links to Bulgaria, in particular:

Maybe I'm backward, but I'm not really a person of that world. It is good to create conditions in Bulgaria so that young people in particular stay here and provide their knowledge here, not to work abroad.... do not want much...to make it even easier to go out because Bulgaria will be left without specialists. And from...third countries, I am for a relaxed regime, their workers already have the option for seasonal employment...and the state makes it easier to hire people....Moldova, the Bessarabian Bulgarians, even Ukraine, we had a lot of people who...wish to come to work here, but it is still difficult. And...the Bessarabian Bulgarians really come and...have a desire to work, they learn the language very quickly, we have...to get them back. So, the conditions for specialists from Moldova and from...Ukraine should be relaxed.

The experts from private agencies made more concrete recommendations. One suggested to improve cooperation between state and private recruiters but was not optimistic about such prospects. The manager of a private company thought that foreign employers should improve the living conditions they provided for the migrants and stop the practice of placing people in caravans or boarding houses where 4-5 people share a single room. Other recommendations were also directed to- 
wards foreign employers: lowering the requirements for mastering the local language or offering free language courses. A manager expressed the opinion that the successful integration was not a matter of policy, but of hard individual efforts-both from the emigrant and the agency recruiter. Overall, proposals ran on avoiding existing bumps on the path rather than redirecting the process or questioning its basic premises.

\section{Conclusion}

In this article we examined the self-reflected practices of labour mediation in the EU by recruiters working in Bulgaria and Romania. The analysis aimed at contributing to a more differentiated understanding of practices from mediators working in public and private agencies in the less-known context of the two countries. The gradual lifting of EU barriers saw a 'migrant industry' emerging with increasingly diversified supply mechanisms. Our interviews with experts and low-level professionals provided a wealth of information about the recent policies and practices applied in the process of transnational labour mediation.

The main line of distinction went along the division between public and private recruiters: we could distinguish between them based on their functions and reflections, not so much on socio-demographic criteria. The personal characteristics of the interviewed professionals - such as gender and age and their similar educational level-did not make a consistent difference in the voiced opinions, quite probably due to the small number in our sample. It was clear that age mattered in the organisational hierarchy in the public agencies, with managers being above forty in both countries, while gender seemed more important in the private companies, with men more visible among the owners and managers.

In the academic literature, 'migration industries' are generally related to terms such as 'commercialisation' and 'commodification' and indicate profit-based facilitation of mobility (Salt \& Stein, 1997). Although the role of public actors in the process is acknowledged (Faist, 2014), less attention is paid in recent research on European and state institutional actors. We addressed this gap in the article by outlining the importance of these public intermediaries in Bulgaria and Romania and comparing them to their private counterparts. The experts in public agencies relied on a wide pool of employers' offers, greater security against fraud, and professionalism, as the focus of their discourse. Dominant in the discourse of private recruiters was the personal link they maintained with job seekers and employers, and the psychological support they provided to emigrants. In addition, private recruiters did a more thorough selection of candidates to provide employers with workers with the right skills but also with high commitment and work ethics. Public actors insisted on impartial mediation while private ones favoured network marketing. While the former defended 'neutrality' of their job, the latter openly aimed at urging and shaping migration. In both cases, however, migrants' success was often related to mediators' assistance. In this sense, their self-reflection went beyond representations of a mere mediation.

All mediators considered that their partners on both sides had one dominant 'mirror' motivationmoney. While migrants looked for higher income, employers sought cheaper labour. Our findings suggest that the recruiters overwhelmingly perceived the 'triangle' employees-intermediaries-employers as asymmetrically structured and employers were acknowledged to have the right to set requirements. While 'good worker' and 'ideal migrant' are increasingly researched in migration literature as social constructs, images of employers are rarely visible. Our interviews indicated that 'honesty' and 'correctness' stood out as employers' most valued characteristics. In other words, 'ideal employers' were possibly imagined as the ones who stuck to their own rules. Further research in this direction is by all means necessary.

The public and private mediators declared a positive evaluation of mobility in the EU. This was, however, focused on the individual benefits, rather than on the contribution to EU's objectives and economic development. The framework of EU mobility and labour market conditions were generally taken for granted and subject to just technical and infrastructural proposals for improvement. At the same time, there were shared concerns about the negative consequences of mobility-such as shortages on the labour market at home and strained relations in migrants' families. It was more likely so in the case of public agents who did not depend on the market conjuncture and sometimes felt free to express views diverging from the official statements.

Observations and conclusions, like those cited above, eventually refer to a developing professional sector (an 'industry') which lacks long established traditions. While it is still early to expect fundamental reassessments of their activities by participants, still recruitment practices in Bulgaria and Romania are embedded enough to allow for (self-)reflections. These are close to official discourses but already attentively expanding beyond them. Intermediaries' views are never neutral and their perceptions of their own interests in the process shape their understandings of the role of agencies, employers and migrants and have an impact on the EU mobility policy implementation. Recruiters in both countries have already become influential actors in the European mobility process and their views and practices deserve further research.

\section{Acknowledgments}

The authors acknowledge the contribution of their colleagues from the Bulgarian and Romanian national teams for conducting the fieldwork and assisting in the interpretation of the data, to the three anonymous reviewers for their highly valuable criticism and sugges- 
tions for improvement of this article, and to all experts from the recruiting agencies who agreed to share their views and experiences.

\section{Conflict of Interests}

The authors declare no conflict of interests.

\section{References}

Alexe, I., Cazacu, A., Ulrich, L., Bojica, M., Stanciugelu, S., \& Mihaila, V. (2011). The fourth wave. The brain drain along the route between Romania-The West. Bucharest: Soros Foundation Romania.

Anderson, B. (2010). Migration, immigration controls and the fashioning of precarious workers. Work, Employment and Society, 24(2), 300-317.

Atoyan, R., Christiansen, L., Dizioli, A., Ebeke, C., Ilahi, N., Ilyina, A., . . . Zakharova, D. (2016). Emigration and its economic impact on Eastern Europe (IMF Staff Discussion Note 16/07). Washington, DC: International Monetary Fund.

Belcheva, M. (2011). Demographic processes and population development. In A. Atanasov (Ed.), Population in Bulgaria at the beginning of the XXI century: State and trends (pp. 48-80). Sofia: Marin Drinov Academic Publishing House.

Beleva, I., \& Dimitrov, M. (2016). Yearly report of the Institute for Economic Research. Sofia: Gorex Press.

Blitz, B. (2014). Migration and freedom. Mobility, citizenship and exclusion. Cheltenham: Edward Elgar.

Bloch, A., \& McKay, S. (2015). Employment, social networks and undocumented migrants: The employer perspective. Sociology, 49(1), 38-55.

Burawoy, M. (1976). The functions and reproduction of migrant labour: Comparative material from Southern Africa and the United States. American Journal of Sociology, 81(5), 1050-1087.

Coe, N. M., Johns, J., \& Ward, K. (2010). The business of temporary staffing: A developing research agenda. Geography Compass, 4(8), 1055-1068.

Cranston, S. (2018). Calculating the migration industries: Knowing the successful expatriate in the global mobility industry. Journal of Ethnic and Migration Studies, 44(4), 626-643.

Cranston, S., Schapendonk, J., \& Spaan, E. (2018). New directions in exploring the migration industries: Introduction to special issue. Journal of Ethnic and Migration Studies, 44(4), 543-557.

Druica, E., \& lanole-Calin, R. (in press). Perceived pull and push factors of healthcare professionals' intention for mobility: The case of Romania. In A. Polese, R. Turaeva, \& R. Urinbayev (Eds.), Mobilities and informality in former socialist spaces. Basingstoke: Palgrave Macmillan.

Faist, T. (2014). Brokerage in cross-border mobility: Social mechanisms and the (re)production of social inequalities. Social Inclusion, 2(4), 38-52.
Findlay, A., McCollum, D., Shubin, S., Apsite, E., \& Krisjane, Z. (2013). The role of recruitment agencies in imagining and producing the 'good' migrant. Social \& Cultural Geography, 14(2), 145-167.

Friberg, I., \& Eldring, L. (Eds.). (2013). Labour migrants from Central and Eastern Europe in the Nordic countries. Patterns of migration, working conditions and recruitment practices (TemaNord 2013:570). Copenhagen: Nordic Council of Ministers.

Gammeltoft-Hansen, T., \& Nyberg-Sørensen, N. (Eds.). (2013). The migration industry and the commercialization of international migration. London and New York, NY: Routledge.

Glaser, B. G., \& Strauss, A. L. (1967). The discovery of grounded theory: Strategies for qualitative research. Chicago, IL: Aldine.

Goschin, Z. (2014). Remittances as an economic development factor. Empirical evidence from the CEE countries. Procedia Economics and Finance, 10, 54-60.

Green, A., Atfield, G., Staniewicz, T., Baldauf, B., \& Adam, D. (2014). Determinants of the composition of the workforce in low skilled sectors of the UK economy: Social care and retail sectors. Warwick: Warwick Institute for Employment Research.

Grey, A. (2002). Jobseekers and gatekeepers: The role of private employment agency in the placement of the unemployed. Work, Employment and Society, 16(4), 655-674.

Harvey, W., Groutsis, D., \& van den Broek, D. (2018). Intermediaries and destination reputations: Explaining flows of skilled migration. Journal of Ethnic and Migration Studies, 44(4), 644-662.

International Labour Organization. (1949). Migration for employment convention No. 97 (Revised). Geneva: ILO.

International Labour Organization. (1997). Private Employment Agencies Convention (No. 181). Geneva: ILO.

International Labour Organization. (2013). Recruitment practices of employment agencies recruiting migrant workers. A review aimed at improving recruitment regulations and drafting recruitment guidelines. Geneva: ILO.

International Labour Organisation. (2017). The migrant recruitment industry. Profitability and unethical business practices in Nepal, Paraguay and Kenya. Geneva: ILO.

Ionescu, L. (2015). Emigration from Eastern Europe with a focus on brain drain. Journal of Economic and Social Statistics, 4(2), 54-74.

Jones, K. (2014). 'It was a whirlwind. A lot of people made a lot of money': The role of agencies in facilitating migration from Poland into the UK between 2004 and 2008. Central and Eastern European Migration Review, 3(2), 105-125.

Kofman, E. (2008). Managing migration and citizenship in Europe: Towards an overarching framework. In C. Gabriel \& H. Pellerin (Eds.), Governing interna- 
tional labour migration: current issues, challenges and dilemmas (pp. 13-26). London and New York, NY: Routledge.

Kostadinova, S. (2007). Bulgarian emigrants: More benefits than losses for Bulgaria. Sofia: Institute for Market Economics. Retrieved from http://ime.bg/pdf_ docs/Migration_Svetla.doc

Krastev, I. (2014). Democracy disrupted: The global politics of protest. Philadelphia, PA: University of Pennsylvania Press.

Krasteva, A. (2014). From migration to mobility: Policies and roads. Sofia: New Bulgarian University.

Markova, E. (2006). The performance of Bulgarian undocumented and legalised immigrants in the Spanish labour market (Sussex Migration Working Paper No. 31). Brighton: Sussex Centre for Migration Research.

Martin, P. (2005). Merchants of labour: Agents of the evolving migration infrastructure (DP/158/2005). Geneva: International Institute for Labour Studies.

Mintchev, V., Markova, E., Misheva, M., Zaharieva, I., Hristova-Balkanska, I., Boshnakov, V., \& Kalchev, Y. (2012). Bulgarian emigration: Theories, policies, empirical studies. Sofia: IKOPIS.

Nyberg-Sørensen, N. (2012). Revisiting the migrationdevelopment nexus: From social networks and remittances to markets for migration control. International Migration, 50(3), 61-76.

Open Society Institute. (2010). Trends in trans-border migration of the labour force and the free movement of people: Effects on Bulgaria. Sofia: OSI. Retrieved from http://osi.bg/downloads/File/OSI_ Report_Migration_2010_MEW.pdf

Organisation for Economic Cooperation and Develop- ment. (2016). Recruiting immigrant workers: Europe. Paris: OECD.

Rolfe, H., \& Hudson-Sharp, N. (2016). The impact of free movement on the labour market: Case studies of hospitality, food processing and construction. London: National Institute of Economic and Social Research.

Salt, J., \& Stein, J. (1997). Migration as a business: The case of trafficking. International Migration Review, 35(4), 67-94.

Shubin, S., Findlay, A., \& McCollum, D. (2014). Imaginaries of the ideal migrant worker: A Lacanian interpretation. Environment and Planning D: Society and Space, $32,466-483$.

Sporton, D. (2013). 'They control my life': The role of local recruitment agencies in East European migration to the UK. Population, Space and Place, 19(5), 443-458.

Stanchev, K. (Ed.). (2005). Bulgarian migration: Incentives and constellations. Sofia: OSI.

Tyldum, G. (2015). Motherhood, agency and sacrifice in narratives on female migration for care work. Sociology, 49(1), 56-71.

Valsan, C., Druica, E., \& lanole, R. (2015). From neoStalinism to sluggish markets: Transition in Romania. In O. Schwarz-Herion \& A. Omran (Eds.), Strategies towards the new sustainability paradigm (pp. 35-48). New York, NY: Springer.

van den Broek, D., Harvey, W., \& Groutsis, D. (2015). Commercial migration, intermediaries and segmentation of skilled migrant employment. Work, Employment and Society, 30(3), 523-534.

Zeleva, R., \& Draganova, M. (2015). Women in migration: Multiplicity of identities. In R. Stoilova, K. Petkova, \& S. Koleva (Eds.), Knowledge as a value, knowledge as a vocation (pp. 365-382). Sofia: East-West.

\section{About the Authors}

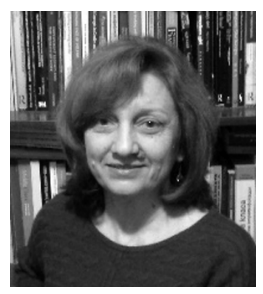

Siyka Kovacheva is Associate Professor in Sociology at the University of Plovdiv, Bulgaria. She is the Head of New Europe Research Centre in the same city. Her research interests are in the field of youth transitions, mobilities and civic participation. She has experience in conducting qualitative and quantitative research in cross-national perspective and has been the national coordinator of more than 10 international comparative research projects.

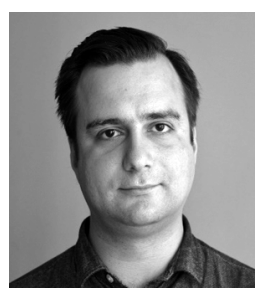

Boris Popivanov is Associate Professor in Political Science at Sofia University and researcher at New Europe Research Centre in Plovdiv, Bulgaria. He works in the areas of youth studies, migration policies as well as the history of political ideas in Europe and Bulgaria, and has participated in international research projects covering these issues.

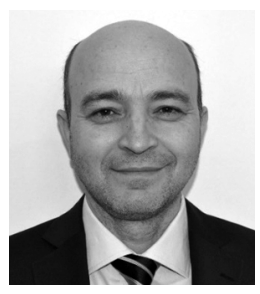

Marin Burcea is Associate Professor at the Faculty of Business and Administration, University of Bucharest, and Researcher at Centre for Urban and Regional Sociology (CURS). Some areas covered by his projects, that reflect his large expertise, are corporate social responsibility, labour market, national identity and applied work in the area of health. He also worked on policy making in healthcare. 